Rev. Int. Contam. Ambie. 34 (4) 697-712, 2018

DOI: 10.20937/RICA.2018.34.04.11

\title{
TEMPORAL VARIABILITY OF MERCURY EMISSIONS FROM A COAL-FIRED POWER PLANT IN MEXICO
}

\author{
Gilberto FUENTES-GARCÍA ${ }^{1 *}$, Humberto BRAVO-ÁLVAREZ ${ }^{\dagger 1}$, Rodolfo SOSA-ECHEVERRÍA ${ }^{1}$, \\ Elías GRANADOS-HERNÁNDEZ ${ }^{2}$ and Sergio ROSAS-DE ALBA ${ }^{1}$
}

${ }^{1}$ Centro de Ciencias de la Atmósfera, Universidad Nacional Autónoma de México, Circuito de la Investigación Científica s/n, Ciudad Universitaria, Ciudad de México, 04510 México, México

${ }^{2}$ Laboratorio de Ingeniería Ambiental, Universidad Nacional Autónoma de México, Centro Tecnológico Aragón, Av. Hacienda de Rancho Seco s/n, Col. Impulsora Popular Avícola, 57130 Nezahualcóyotl, Estado de México, México

*Author for correspondence: fuenbeto@me.com

(Received June 2017; accepted February 2018)

${ }^{\dagger}$ Dr. Humberto Bravo-Álvarez was a pioneer in the study of atmospheric deposition in Mexico. He passed away on March 28, 2017 after a fruitful career that spanned for more than 50 years.

Key words: atmospheric pollution, emission factor, coal, electricity generation

\begin{abstract}
According to the Minamata Convention it is necessary to determine the mercury emissions from coal-fired power plants in Mexico due to Mexico's responsibility to reduce its mercury emissions into the atmosphere. For this purpose, we used the coal consumption data provided directly by the Federal Electricity Commission of Mexico, which include emissions per day and per generating unit for the year 2013. To determine the mercury emissions from a coal-fired power plant in Mexico, we used the US Environmental Protection Agency methodology and focused on the Presidente Plutarco Elías Calles (CETEPEC) power plant, because in Mexico there are no methodologies to determine mercury emissions from coal-fired power plants. The results show that mercury emissions from units 1 to 6 of the CETEPEC plant range from 0.5 to $1.2 \mathrm{~kg}$ / day; however, emissions from unit 7 are as high as $2 \mathrm{~kg}$ /day. The total mercury emissions from the CETEPEC power plant in 2013 were $1942 \mathrm{~kg}$, of which $1698 \mathrm{~kg}$ were gaseous elemental mercury $\left(\mathrm{Hg}^{0}\right), 243 \mathrm{~kg}$ gaseous oxidized mercury $\left(\mathrm{Hg}^{2+}\right)$, and 1.2 $\mathrm{kg}$ particle-bound mercury $\left(\mathrm{Hg}_{\mathrm{p}}\right)$. This study is relevant in Mexico and indicates an advance on the control of mercury emissions from the CETEPEC power plant, in accordance to the Minamata Convention.
\end{abstract}

Palabras clave: contaminación atmosférica, factor de emisión, carbón mineral, generación de electricidad

\section{RESUMEN}

De acuerdo con el Convenio de Minamata, es necesario determinar las emisiones de mercurio de las centrales eléctricas a base de carbón en México, debido a que este país tiene la responsabilidad y el compromiso de reducir su emisión de mercurio a la 
atmósfera. Para ello utilizamos la información sobre consumo de carbón suministrada directamente por la Comisión Federal de Electricidad por día y por unidad de generación eléctrica en 2013. Para determinar la emisión de mercurio de una carboeléctrica en México utilizamos la metodología de la Agencia de Protección Ambiental de los Estados Unidos, considerando la concentración de mercurio en el carbón y el consumo de carbón por unidad generadora de la planta de energía Presidente Plutarco Elías Calles (CETEPEC), debido a que en México no existen metodologías para determinar la emisión de mercurio de las centrales eléctricas de carbón. Los resultados obtenidos para este estudio indican que las unidades 1 a 6 de CETEPEC presentaron un nivel de emisión de mercurio de 0.5 a $1.2 \mathrm{~kg} /$ día a la atmósfera; sin embargo, la unidad 7 presentó una emisión de mercurio cercana a $2 \mathrm{~kg} /$ día. La emisión total de mercurio de la central CETEPEC en 2013 fue de $1900 \mathrm{~kg}$, de los cuales $1698 \mathrm{~kg}$ fueron de mercurio en fase vapor, $243 \mathrm{~kg}$ de mercurio reactivo y $1.2 \mathrm{~kg}$ de mercurio en forma de partícula. Este estudio es relevante para México e indica un avance en la reducción de emisiones de mercurio de la central CETEPEC, acorde con el Convenio de Minamata firmado por México desde 2013.

\section{INTRODUCTION}

Three coal fired-power plants have recently been installed in Mexico, which use domestic and imported coal (mainly from the USA) to generate electricity. The control systems of these coal-fired power plants are primarily electrostatic precipitators (ESPs), which results in virtually all mercury being emitted into the atmosphere, leaving only a small amount in the bottom ash and slag, and in the fly ash (USEPA 2005, 2011). Insufficient studies have been conducted about the mercury in the coal used by Mexican power plants, and mercury emissions from these power plants, because there is not a national standard maximum emission level.

The Minamata Convention on mercury, signed by 140 countries including Mexico since 2013, agreed to reduce mercury emissions into the atmosphere, and to identify power plants that use coal to generate electricity (UNEP 2015). Analyzing the mercury content in domestic and imported coal used for electricity generation at the three coal-fired power plants operating in Mexico and determining their mercury emissions is an important task.

In this study, mercury emissions for 2013 from the CETEPEC power plant were calculated using the USEPA methodology and information about fuel consumption per day and generating unit provided directly by the Federal Electricity Commission of Mexico. The obtained daily mercury emissions for 2013 will be useful in further studies of mercury emissions for this and other coal-fired power plants in Mexico (Carbón I and Carbón II). Considering the daily fuel consumption per unit of electricity generated, we can understand and propose control measures to increase the efficiency of each unit to reduce mercury emissions.

Since this study only uses information from the CETEPEC power plant for the year 2013, we think this information should be updated with additional data for the power plants Carbón I and Carbón II, which it will reflect a very important advance towards complying with the Minamata Convention.

\section{Background}

Gaseous elemental mercury (GEM), gaseous oxidized mercury, and particulate bound mercury (PBM) are persistent, toxic, and bio-accumulative pollutants in water, soil, and air (UNEP 2013, NADP 2015, USEPA 2015a, b). Galbreath and Zygarlicke (2000) reported that GEM, GOM and PBM are formed during the combustion of coal. Coal contains trace amounts of mercury (typically from 0.01 to $0.5 \mathrm{mg}$ / $\mathrm{kg}$ ), which are emitted as GEM when coal is combusted at approximately $150{ }^{\circ} \mathrm{C}$ (Senior et al. 2000, Hassett et al. 2002, 2004, Heebink and Hassett 2005, Zhang and Wong 2007, Wang et al. 2010).

GEM can travel many thousands of kilometers from its emission source, therefore it has a global impact (Schroeder and Munthe 1998, Streets et al. 2009, Pacyna et al. 2010). PBM falls to the ground near its emission source, whereas GOM is oxidized and reduced to other forms in the atmosphere. The environmental effects of PBM and GOM are manifest at local and regional scales (Pavlish et al. 2003).

Zhang et al. (2008) demonstrated that PBM and GOM might be efficiently retained by the emissions control systems of electrical facilities such as electrostatic precipitators, desulfurizers, and fabric filters. Moreover, Wang et al. (2010) recommended the use 
of a combination of control systems (electrostatic precipitator and desulphurizer) to reduce mercury emissions $73 \%$, compared with $24 \%$ when an electrostatic precipitator is used alone. Pirrone et al. $(2001,2010)$ indicated that desulfurizers can be used in control systems but are not commonly used in developing countries or those with economies in transition.

\section{Mercury emissions from Mexico}

Three coal-fired power plants are installed in Mexico. Two operate in the north of the territory (Carbón I and Carbón II in the state of Coahuila), both using domestic (90\%) and imported coal (10\%), mainly come from the USA, Australia and South Africa. The third plant, referred as Presidente Plutarco Elías Calles (CETEPC), is located in the Pacific coast (in the state of Guerrero) and operates $100 \%$ on imported coal, mainly from the USA.

Considering how toxic and persistent is the presence of mercury in the atmosphere, Sosa et al. (2014, 2017) investigated the mercury emissions from 2012 to 2013 using monthly coal consumption data provided directly by the industrial sector for the three Mexican coal-fired power plants, and Fuentes et al. (2017) reported the spatiotemporal variability of atmospheric mercury using per-day and per-generatingunit data of one coal-fired power plant (CETEPEC) in Mexico. Fuentes et al. (2017) reported that mercury concentration in the coal from a Kansas mine in the USA, which is used by CETEPEC, was $0.335 \mathrm{mg}$ $\mathrm{Hg} / \mathrm{kg}$ of coal, and Múgica et al. (2003) reported a concentration of $0.333 \mathrm{mg} \mathrm{Hg} / \mathrm{kg}$ in Mexican coal.

Table I shows the mercury emissions from coalfired power plants by country. Mexico did not report mercury emissions between 2008 and 2011, thus it is very important that Mexican institutions provide better emissions thereafter. In general, Mexico does not have major problem regarding mercury emissions in a worldwide level, since they are very low compared with South Africa, India, Australia, China, and the USA. This is primarily due to the fact that Mexico has only three coal-fired power plants, while other countries have hundreds of these facilities for the generation of electricity. Therefore, Mexico's mercury emissions do not represent an impact on worldwide levels, but it is necessary to identify if there are national or local effects near the sites of these plants. For the North American region (Canada, Unites States, and Mexico), Canada had minor mercury emissions from 2011 to 2013, because its power plants only work in the periods of peak energy demand (hours, days or weeks), according to CEC (2011). The USA presents the highest levels of mercury emissions within the region; however, the USA government is restricting mercury emissions with technologies and specific control systems. In Mexico, according to the Secretaría de Energía (Ministry of Energy) of Mexico, the three coal-fired power plants are working continuously for electricity generation, and the control system is an electrostatic precipitator that does not completely retain the mercury emissions (SENER 2015).

The technical data about the three coal-fired power plants in Mexico is shown in table II. There are 15 generating units in Mexico, all of them with a control system corresponding to the electrostatic precipitator type, which retains pollutants' particles with $97 \%$ efficiency. The CETEPEC power plant has a major electricity generation capacity - near 700 MW - , much higher than Carbón I and II. The plant factor is the relation between electricity generated in a specific period (commonly an annual period) and the total generating capacity of the plant. The plant factor can never be $100 \%$ due to the maintenance of the power plant and the equipment for electricity generation, as well as other considerations.

Table III shows estimated mercury emissions for

TABLE I. MERCURY EMISSIONS ( $\mathrm{t}$ ) FROM COAL-FIRED POWER PLANTS BY COUNTRY

\begin{tabular}{lccccccccccccc}
\hline Country & 1990 & 1999 & 2001 & 2002 & 2004 & 2005 & 2008 & 2009 & 2010 & 2011 & 2012 & 2013 & In this study \\
\hline USA $^{1}$ & 60 & 60 & & 55 & & 49 & 29 & & 66 & 26 & 40 & 46 & \\
Canada $^{2}$ & 1.3 & 2.2 & - & - & - & 2.1 & 1.5 & 1.6 & 1.4 & 0.9 & 0.8 & 0.8 & Mexican \\
Mexico $^{3,4,5,6,7}$ & 1.6 & 2.2 & 0.97 & 1.1 & 2.9 & 1.9 & - & - & - & - & 1.7 & 1.6 & CETEPEC \\
China $^{8}$ & - & 68 & 62 & 69 & 91 & 100 & 257 & 257 & 253 & - & - & - & power plant: \\
Australia $^{9}$ & - & - & - & - & - & 8 & - & - & - & - & 2.8 & 2.8 & $1.9 \mathrm{t}$ \\
India $^{10}$ & - & - & - & - & 120 & 96 & 120 & - & - & - & 100 & 100 & 123 \\
South Africa $^{11}$ & - & - & - & - & 31 & - & - & - & - & 125 & 124 & 123 \\
\hline
\end{tabular}

${ }^{1} \mathrm{USEPA}(2017),{ }^{2} \mathrm{ECCC}(2017),{ }^{3}$ Acosta y Asociados (2001), ${ }^{4}$ Vijay et al. (2004), ${ }^{5}$ Larralde (2004), ${ }^{6} \mathrm{CEC}(2011),{ }^{7}$ Sosa et al. (2014, 2016), ${ }^{8} \operatorname{MEP}(2016),{ }^{9} \mathrm{DEE}$ (2017), ${ }^{10} \mathrm{MEFCC}$ (2017), ${ }^{11} \mathrm{DEA}(2017)$ 
TABLE II. TECHNICAL DATA INFORMATION ABOUT THE THREE COAL-FIRED POWER PLANTS INSTALLED IN MEXICO

\begin{tabular}{lccccccc}
\hline $\begin{array}{l}\text { Coal } \\
\text { fired-power } \\
\text { plant }\end{array}$ & State & $\begin{array}{c}\text { Generating } \\
\text { units }\end{array}$ & $\begin{array}{c}\text { Total } \\
\text { capacity } \\
(\mathrm{MW})\end{array}$ & $\begin{array}{c}\text { Total electricity } \\
\text { generation } \\
(\mathrm{GW} \mathrm{h})\end{array}$ & $\begin{array}{c}\text { Average electricity } \\
\text { generation } \\
(\mathrm{GW} \mathrm{h})\end{array}$ & $\begin{array}{c}\text { Plant } \\
\text { factor } \\
(\%)\end{array}$ & $\begin{array}{c}\text { Control } \\
\text { system }\end{array}$ \\
\hline Carbón I & Coahuila & $4 \times 300 \mathrm{MW}$ & 1200 & 10512 & 9200 & 88 & Electrostatic \\
Carbón II & Coahuila & $4 \times 350 \mathrm{MW}$ & 1400 & 12264 & 10300 & 84 & precipitator \\
CETEPEC & Guerrero & $6 \times 350 \mathrm{MW}$ & 2778 & 24335 & 18000 & 74 \\
\hline
\end{tabular}

the three coal-fired power plants located in Mexico according to Sosa et al. (2014). These estimates were calculated using the USEPA methodology, assuming a mercury concentration in coal of $0.113 \mathrm{mg} / \mathrm{kg}$. Table IV shows mercury emissions estimated by Sosa et al. (2017) using the mercury emission rate.

TABLE III. MERCURY EMISSIONS BY THE THREE COAL-FIRED POWER PLANTS FROM MEXICO ACCORDING TO SOSA et al. (2014)

\begin{tabular}{lcc}
\hline Coal fired-power plant & \multicolumn{2}{c}{ Mercury emission $(\mathrm{kg} /$ year $)$} \\
\cline { 2 - 3 } & 2012 & 2013 \\
\hline Carbón I & 566 & 505 \\
Carbón II & 515 & 472 \\
CETEPEC & 665 & 659 \\
Total & 1746 & 1636 \\
\hline
\end{tabular}

TABLE IV. MERCURY EMISSIONS BY THE THREE COALFIRED POWER PLANTS FROM MEXICO ACCORDING TO SOSA et al. (2016)

\begin{tabular}{lcc}
\hline Coal fired-power plant & \multicolumn{2}{c}{ Mercury emission (kg/year) } \\
\cline { 2 - 3 } & 2012 & 2013 \\
\hline Carbón I & 526 & 469 \\
Carbón II & 478 & 438 \\
CETEPEC & 4477 & 4433 \\
Total & 4477 & 4433 \\
\hline
\end{tabular}

According to the USEPA (2011) it is very important to determine the GEM, GOM and PBM from a coal-fired power plants that use emission control systems such as electrostatic precipitators or consumption of coal by type (subbituminous or bituminous). Mexico does not have a methodology to determine those fractional mercury emissions directly in the power plant, and the USEPA indicates that the fraction of GEM, GOM and PBM is $87.41,12.52$ and $0.06 \%$, respectively (USEPA 2011).

Also, it is very important to consider the mercury mass balance in the CETEPEC power plant, to determine how much is emitted to the atmosphere and how much was not combusted into the boiler and remains in the solid matter. The fractions corresponding to bottom ash, slag, and fly ash are 11,5 , and $84 \%$, respectively (USEPA 2002, 2011).

\section{CETEPEC technical data information}

Currently, the CETEPEC power plant has seven power generating units and a total capacity for electricity generation of about $2778 \mathrm{MW}$. The generating units 1 (U1) to 6 (U6) have a daily coal consumption per unit of about 3000 t; however, generation unit 7 (U7) has a daily coal consumption of about $6000 \mathrm{t}$. The combustion system uses pulverized coal, a system of emission control of low nitrogen oxides (NOx), and electrostatic precipitators for each generating unit. However, there is no control system for sulfur dioxide $\left(\mathrm{SO}_{2}\right)$, and it does not have washers of output gases for the retention of mercury. Personnel of the CETEPEC power plant indicated that, of the total coal consumed in the process to generate electricity, $10 \%$ corresponds to ash types (bottom, slag, and fly); from this percentage, $16 \%$ correspondes to bottom ash and slag from the boiler, and $84 \%$ to fly ash from the control system. The CETEPEC administration does not perform the elemental analysis of the coal discharge. That is why this study is relevant for the proposal prevention measures, and the minimization and control of a toxic contaminant such as mercury, originating from the coal-fired power plants installed in Mexico.

\section{MATERIALS AND METHODS}

The method for calculating mercury emissions into the atmosphere considered the mercury concentration in coal and the modified emission factor 
(USEPA 1997), from which the following equation is obtained:

Hg emission,

$$
\begin{gathered}
=\left(\text { mercury concentration, } \frac{\mathrm{kg}, \mathrm{Hg}}{t, \text { coal }}\right) \\
\left(\text { coal consuption, } \frac{t, \text { coal }}{\text { month }}\right)(M E F)
\end{gathered}
$$

This equation accounts for mercury content in the coal. For this study, we used Eq. (1) because mercury concentration is different in the coal used by coalfired power plants. To determine the mercury emission, we used a concentration of $0.335 \mathrm{mg} \mathrm{Hg} / \mathrm{kg}$ of coal, determined by Fuentes et al. (2017) for Mexico.

Control systems used by coal-fired power plants installed in Mexico correspond to electrostatic precipitators with value 1 , as recommended by the tables developed by the USEPA (1997). In this case mercury emissions are not retained in the control system because they are released as gaseous elemental mercury (GEM). The modified emission factor with value 1 indicates that the GEM is emitted totally into the atmosphere because the ESP retains non-gaseous pollutant particles as GEM. This information corresponds to the USEPA methodology; however, in order to identify mercury emissions into the atmosphere, we determined the fractional GEM, GOM and PBM, as well as the mercury mass balance, in the following manner:

For GEM, GOM and PBM from coal-fired power plants that use electrostatic precipitators and consumption of coal by type (subbituminous or bituminous), we used the profile of GEM, GOM and PBM corresponding to $87.41,12.52$ and $0.06 \%$, respectively (USEPA 2011).
To consider the mercury mass balance in the CETEPEC power plant, we contemplated information about the total coal consumed in the process of generating electricity, of which $10 \%$ corresponds to ash types (bottom, slag and fly); of these, $16 \%$ corresponds to bottom ash and slag from the boiler, and $84 \%$ to fly ash from the electrostatic precipitator and control system.

\section{RESULTS AND DISCUSSION}

Mercury emissions from the CETEPEC power plant calculated by Eq. (1) enable the identification of the temporal variability of mercury emissions per day and per generating unit.

Table $\mathbf{V}$ shows the results for mercury emissions from each generating unit of the CETEPEC power plant for 2013. We can note the working days for each generating unit. U7 shows the highest emissions (near $2 \mathrm{~kg} /$ day) of mercury into the atmosphere. The daily standard deviation of mercury emissions for each generating unit is low.

The temporal variability of mercury emissions per day is illustrated in figure 1. From April to July there was an increase in electricity generation, since in this time of the year (spring-summer) air conditioning systems operate at $100 \%$ of their capacity. The highest mercury emissions (above $7.5 \mathrm{~kg}$ /day) from all units occurred in April 19, 24, and 25, with $7.53,7.56$, and $7.59 \mathrm{~kg} /$ day, respectively; May 2 and 3, with 7.52 and $7.57 \mathrm{~kg} /$ day, respectively. Total mercury emissions in 2013 were $1943 \mathrm{~kg}$ of mercury into the atmosphere from all units.

Table VI presents emissions of gaseous elemental mercury $\left(\mathrm{GEM}, \mathrm{Hg}^{0}\right)$, gaseous oxidized mercury $\left(\mathrm{GOM}, \mathrm{Hg}^{2+}\right)$, and particle bound mercury (PBM, $\mathrm{Hg}_{\mathrm{p}}$ ) from the CETEPEC power plant in 2013. GEM is the major emission with respect to GOM and PBM,

TABLE V. STATISTICAL PARAMETERS FOR MERCURY EMISSIONS (kg/year) BY EACH GENERATING UNIT OF THE CETEPEC POWER PLANT

\begin{tabular}{lccccccc}
\hline Parameter & U1 & U2 & U3 & U4 & U5 & U6 & U7 \\
\hline Data (days) & 335 & 213 & 230 & 319 & \multicolumn{1}{c}{305} & 258 & \multicolumn{1}{c}{325} \\
Total emission & 293.8 & 134.6 & 195.9 & 273.5 & 260.0 & 227.2 & 556.9 \\
Maximum/day & 1.09 & 0.71 & 1.04 & 1.04 & 1.07 & 1.05 & 1.92 \\
Minimum/day & 0.05 & 0.01 & 0.01 & 0.00 & 0.01 & 0.18 & 0.29 \\
Average & 0.88 & 0.63 & 0.85 & 0.86 & 0.85 & 0.88 & 1.71 \\
Standard deviation & 0.17 & 0.09 & 0.16 & 0.18 & 0.17 & 0.13 & 0.17 \\
25th percentile & 0.84 & 0.63 & 0.82 & 0.85 & 0.79 & 0.86 & 1.66 \\
50th percentile & 0.92 & 0.65 & 0.89 & 0.90 & 0.91 & 0.91 & 1.74 \\
75th percentile & 0.98 & 0.66 & 0.95 & 0.95 & 0.95 & 0.96 & 1.81 \\
\hline
\end{tabular}




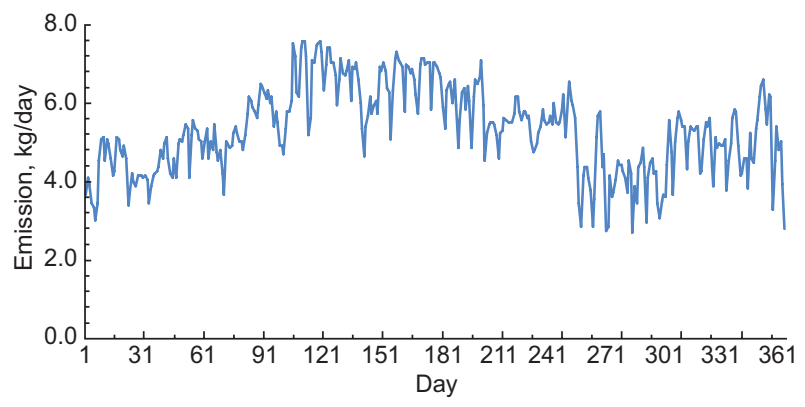

Fig. 1. Daily mercury emissions from the CETEPEC power plant in 2013

TABLE VI. MERCURY EMISSIONS IN 2013: GASEOUS ELEMENTAL MERCURY (GEM), GASEOUS OXIDIZED MRECURY (GOM) AND PARTICLE BOUND MERCURY (PBM) USING THE USEPA METHODOLOGY ${ }^{1}$

\begin{tabular}{ccccc}
\hline \multicolumn{6}{l}{ CETEPEC power plant } & & & \\
\hline $\begin{array}{c}\text { Generating } \\
\text { unit }\end{array}$ & $\begin{array}{c}\text { Emission } \\
(\mathrm{kg})\end{array}$ & $\begin{array}{c}\text { GEM } \\
(\mathrm{kg})\end{array}$ & $\begin{array}{c}\text { GOM } \\
(\mathrm{kg})\end{array}$ & $\begin{array}{c}\text { PBM } \\
(\mathrm{kg})\end{array}$ \\
\hline 1 & 294 & 257 & 37 & 0.18 \\
2 & 135 & 118 & 17 & 0.08 \\
3 & 196 & 171 & 25 & 0.12 \\
4 & 274 & 240 & 34 & 0.16 \\
5 & 260 & 227 & 33 & 0.16 \\
6 & 227 & 198 & 28 & 0.14 \\
7 & 557 & 487 & 70 & 0.33 \\
Total & 1943 & 1698 & 244 & 1.17 \\
\hline
\end{tabular}

${ }^{1}$ USEPA (2011)

due to the control system installed in CETEPEC corresponding to the electrostatic precipitator. U7 presented the highest mercury emission as GEM, since it consumes about $6,000 \mathrm{t}$ of coal per day due to its high capacity for electricity generation (about $700 \mathrm{MW})$.

To estimate mercury mass balance in CETEPEC it was necessary to consider the mercury concentration in coal $(0.335 \mathrm{mg} / \mathrm{kg})$, mercury concentration in bottom ash and slag $(0.148 \mathrm{mg} / \mathrm{kg})$, and mercury concentration in fly ash $(0.017 \mathrm{mg} / \mathrm{kg})$, all of them analyzed by Fuentes et al. (2017). CETEPEC consumed $5832666 \mathrm{t}$ of coal in 2013, $10 \%$ (583266 t) corresponding to bottom ash and slag, and fly ash. Table VII shows the mercury retained in the boiler and electrostatic precipitator, and the GEM emitted into the atmosphere, while figure $\mathbf{2}$ presents the mercury mass balance diagram considering the boiler and control system (electrostatic precipitator).

Figure 3 illustrates daily mercury emissions for each generating unit during May, as a case example. U7 emitted the highest amount of mercury, and all generating units were working during that month. Average mercury emitted into the atmosphere from U7 was $1.8 \mathrm{~kg}$, due to its generating capacity of 700 MW; moreover, each generating unit from U1 to U6 have a generating capacity of $350 \mathrm{MW}$, and their average emission of mercury into the atmosphere was $0.9 \mathrm{~kg}$. Similarly, some generating units were sometimes out of service for a few days or months because they were undergoing maintenance. A slightly higher amount of electricity was generated during April-July because most of the units were working and it was the period of greatest energy demand. Appendix 1 shows the daily mercury emissions for each month during 2013.

Table VIII shows mercury emission rates for each generating unit during 2013. The values presented in this table are high as compared to mercury emissions from the USA( 0.0059 to $0.054 \mathrm{~kg} \mathrm{Hg} / \mathrm{GW} \mathrm{h}$ ) (NRDC 2012) due to the newer technologies employed in this country for control systems, such as fabric filters, selective catalytic reactors, and activated carbon injection.

The efficiency of each electricity-generating unit during 2013 is shown in figure 4. The efficiency of U7 was consistently higher than $90 \%$, whereas U2 was less efficient. This figure also indicates periods during which some generating units were not working.

TABLE VII. MERCURY MASS BALANCE IN THE CETEPEC POWER PLANT CONSIDERING 583266 t FOR ASH TYPES

\begin{tabular}{lcccccc}
\hline Type & Composition & Profile & $\begin{array}{c}\text { Mercury } \\
\text { concentration }\end{array}$ & Hg input & $\begin{array}{c}\mathrm{Hg} \\
\text { output }\end{array}$ & $\begin{array}{c}\mathrm{Hg} \text { as gaseous } \\
\text { elemental mercury }\end{array}$ \\
\hline $\begin{array}{l}\text { Sub-bituminous coal } \\
\begin{array}{l}\text { Bottom ash and slag, } \\
\text { from boiler }\end{array}\end{array}$ & - & - & $0.335 \mathrm{mg} / \mathrm{kg}$ & $1954 \mathrm{~kg}$ & - & $1879 \mathrm{~kg}$ \\
$\begin{array}{l}\text { Fly ash, from control } \\
\text { system }\end{array}$ & $84 \%$ & $489943 \mathrm{t}$ & $0.148 \mathrm{mg} / \mathrm{kg}$ & - & $73 \mathrm{~kg}$ & \\
\hline
\end{tabular}




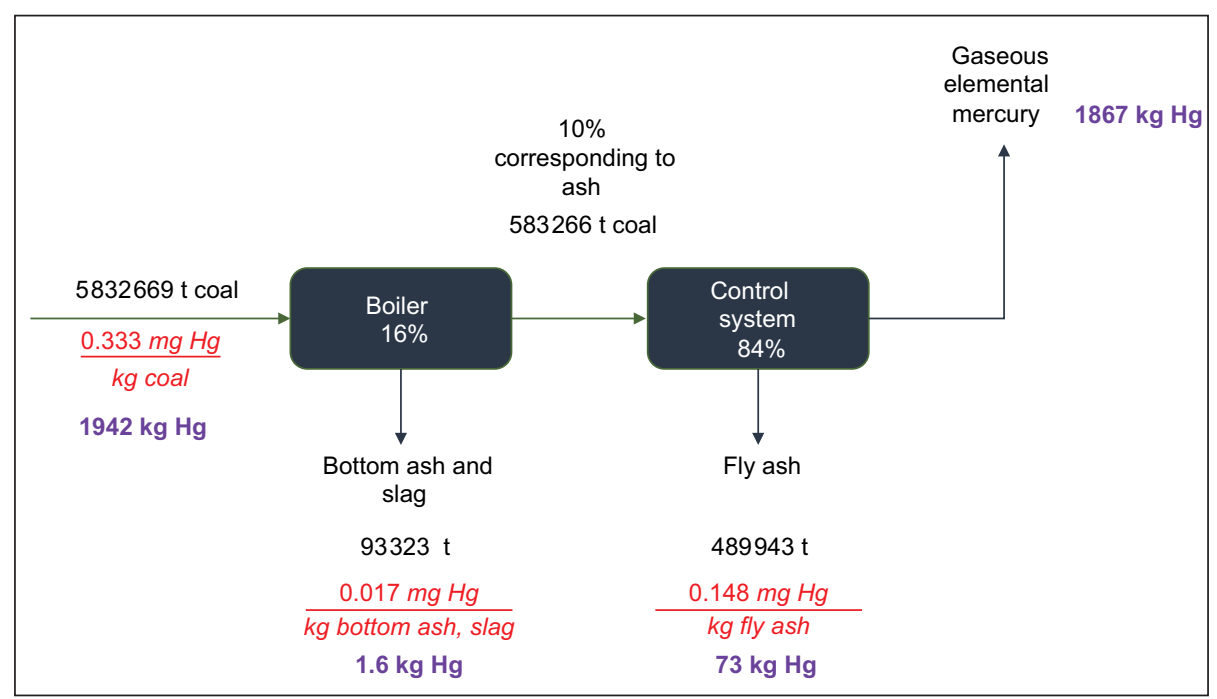

Fig. 2. Mercury mass balance diagram

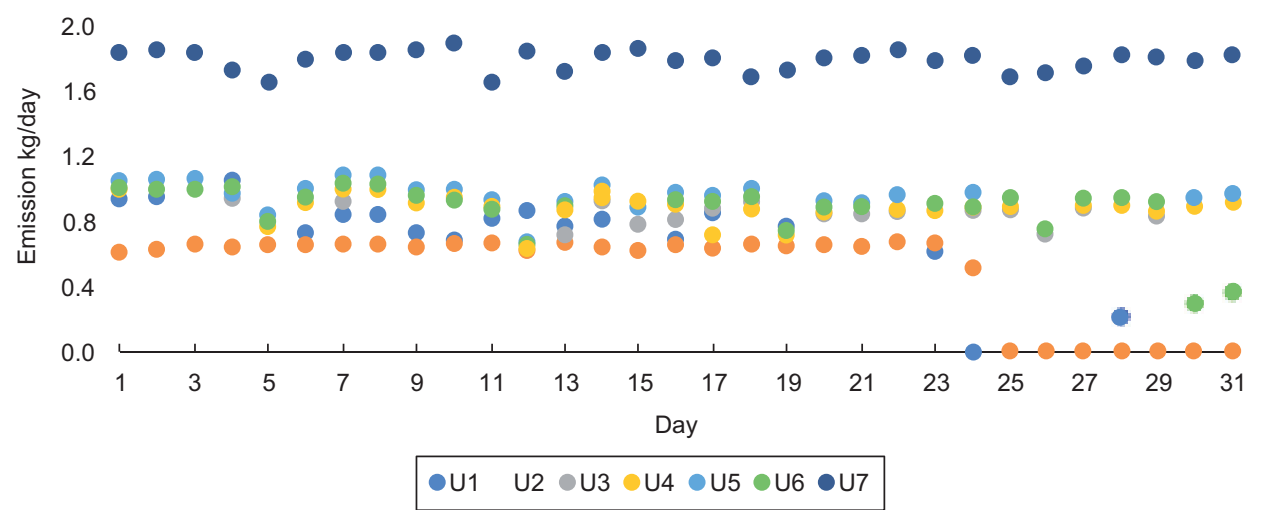

Fig. 3. Daily mercury emissions from each generating unit in May 2013

TABLE VIII. MERCURY EMISSION RATES FROM THE CETEPEC POWER PLANT IN 2013

\begin{tabular}{cccc}
\hline Unit & $\begin{array}{c}\text { Mercury } \\
\text { emission }(\mathrm{kg})\end{array}$ & $\begin{array}{c}\text { Electricity } \\
\text { generation }(\mathrm{GW} \mathrm{h})\end{array}$ & $\begin{array}{c}\text { Emission } \\
\text { rate }(\mathrm{kg} \mathrm{Hg} / \mathrm{GW} \mathrm{h})\end{array}$ \\
\hline $\mathrm{U} 1$ & 294 & 2272 & 0.1294 \\
$\mathrm{U} 2$ & 135 & 1041 & 0.1296 \\
$\mathrm{U} 3$ & 196 & 1512 & 0.1296 \\
$\mathrm{U} 4$ & 274 & 2124 & 0.1290 \\
U5 & 260 & 2051 & 0.1267 \\
U6 & 227 & 1771 & 0.1281 \\
U7 & 557 & 4813 & 0.1157 \\
\hline
\end{tabular}

The percentage of total electricity generation supplied by unit in the CETEPEC plant during 2013 is presented in figure 5. U7 had the highest performance (31\%), whereas U2 had the lowest (7\%) because it was out of service for several months. The other units accounted between 10 and $14 \%$ of the capacity. CETEPEC administration should consider the performance of U7 during the period of major demand for electricity generation.

Figure 6 illustrates the amount of mercury emitted seasonally in 2013 by each generating unit of the CETEPEC plant. All units were working during the spring-summer season because of the high energy demand during this period. During autumn some generating units were working below their capacity, but mercury emissions from U7 were always above $90 \%$ of efficiency for electricity generation.

Figure 7 presents the variability of mercury emissions of each generating unit. U2 presented the lowest mercury emissions since it was out of service for several months. The variability of mercury emissions from U1 to U6 was similar and 


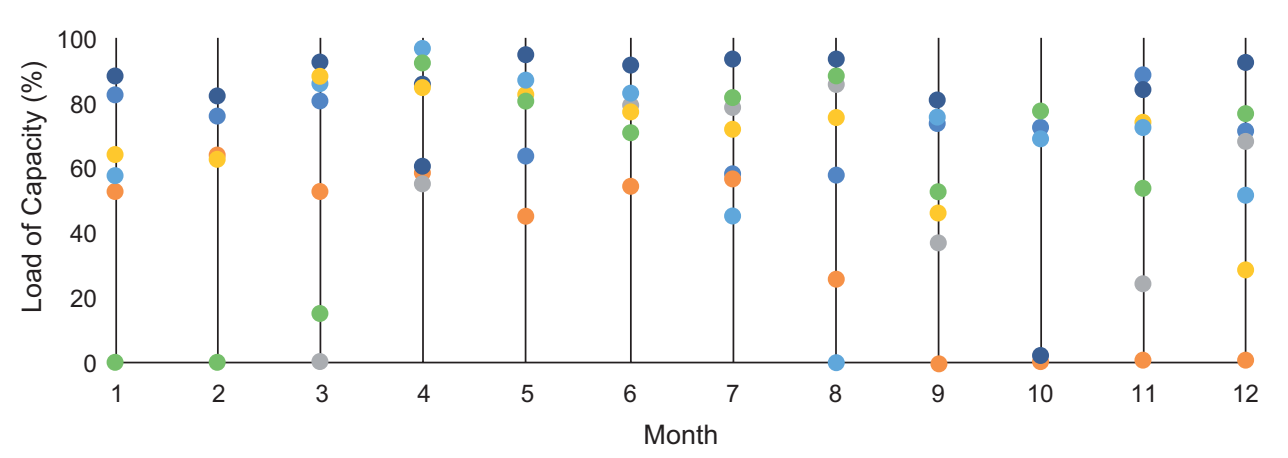

$\bullet U 1 \bullet U 2 \bullet U 3 \bullet U 4 \bullet U 5 \bullet U 6 \bullet \cup 7$

Fig. 4. Percentage used of the load capacity for each generating unit during 2013

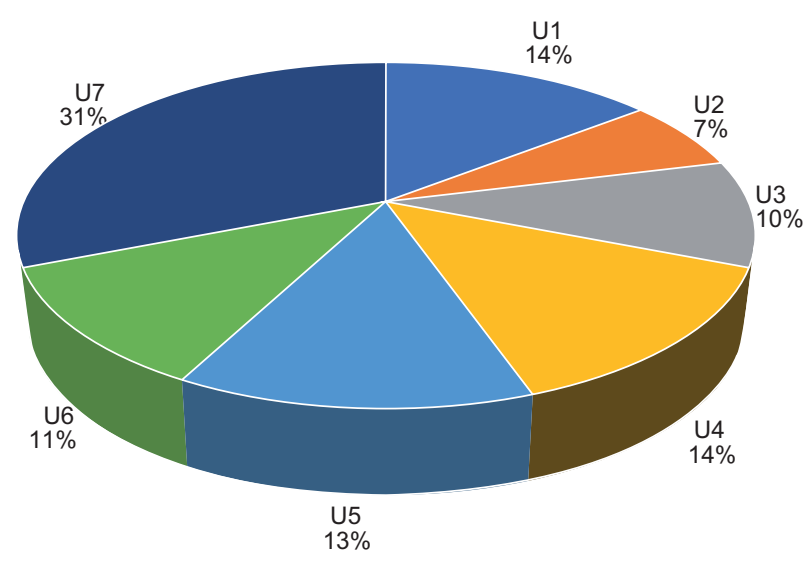

Fig. 5. Percentage of the plant's total electricity generation supplied by unit of CETEPEC in 2013

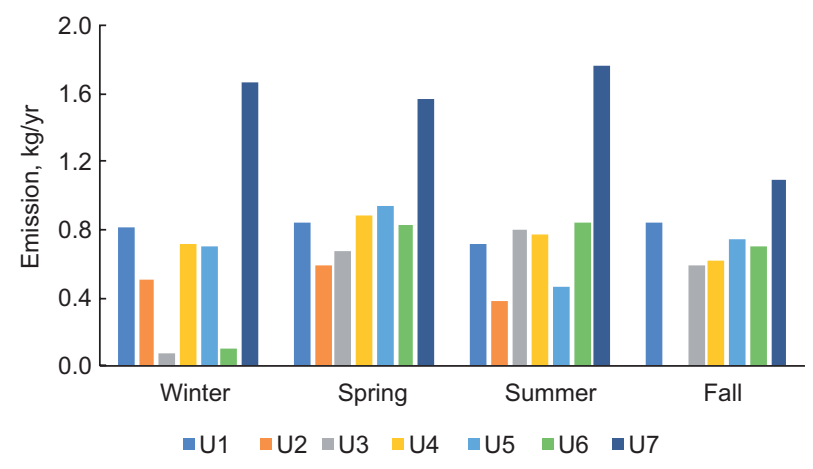

Fig. 6. Mercury emitted seasonally by each generating unit during 2013

fell within the 50 th percentile $(0.93 \mathrm{~kg} /$ day $)$. The 25 th percentile was about $0.83 \mathrm{~kg} /$ day, and the $75 \mathrm{th}$ percentile was about of $0.95 \mathrm{~kg} /$ day. Regarding U7, the 50th, 25th, and 75th percentiles were 1.74, 1.7,

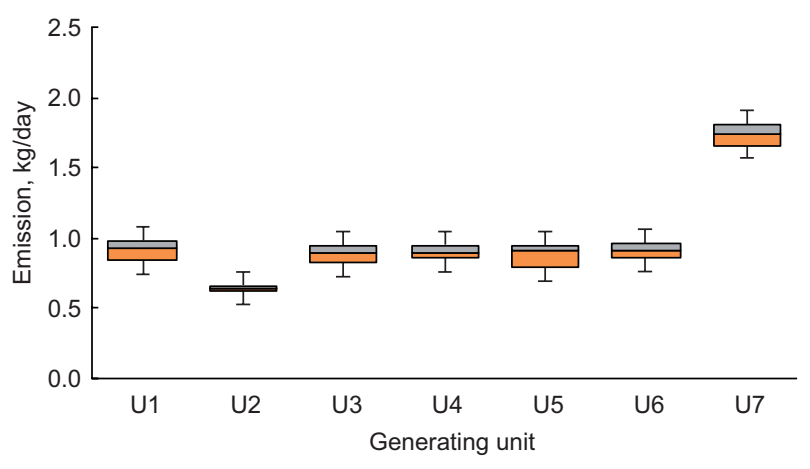

Fig. 7. Mercury emissions for each generating unit during 2013

and $1.81 \mathrm{~kg} / \mathrm{day}$, respectively. The standard deviation is low with respect to the average, indicating that the variability of mercury emissions by each generating unit is low.

\section{CONCLUSIONS}

Since in Mexico there is no methodology to determine mercury emissions from its coal-fired power plants, we used the USEPA methodology to estimate mercury emissions from the CETEPEC power plant; however, the most important issue is to generate the emission factors for power plants in Mexico.

Using data information about coal consumption per day and per generating unit provided more reliable mercury emissions, and it also helps to find measures of prevention, minimization and control for each electricity-generating unit.

The period of major demand of electricity generation occurred from April to July, therefore mercury 
emissions were higher, which confirms that it is necessary to evaluate the load and efficiency of each generation unit during this period.

U7 had the highest mercury emissions into the atmosphere since the load of coal of this generating unit was $95 \%$ of its capacity, and it worked for a longer time in electricity generation during 2013.

GEM emissions were larger than other forms of mercury, so it is necessary to develop new technologies to retain this gas according to the Minamanta Convention for the next years. Considering all the generation units, U7 released the larger amount of GEM into the atmosphere, thus it is important to evaluate this generating unit in the period corresponding to the electricity generation demand in Mexico.

The mercury emission rate for each generating unit was high with respect to the level reported by the USA, thus it is very important that the CETEPEC administration adopts new technologies to reduce the mercury emission rate.

Mexico should plan and implement energy generation alternatives, including reconfiguring or building next-generation power plants that operate at optimal efficiency and emit less mercury into the atmosphere.

The mercury emissions discussed in this study are very relevant because our country has a commitment to reduce them during the following years according to the Minamata Convention signed in 2013.

\section{ACKNOWLEDGMENTS}

We acknowledge the collaboration of Elizabeth Vega Rangel, Ana Luisa Alarcón J., María del Carmen Torres B., Pablo Sánchez A., and Mónica Jaimes P. of the Sección de Contaminación Ambiental del Centro de Ciencias de la Atmósfera, UNAM. We also acknowledge the collaboration of Claudia García L., Sally Bravo W., and María de los Ángeles López P., for the English translation, as well as Norma Popoca M. of the Comisión Federal de Electricidad. We thank CONACyT for providing scholarship support for the doctoral study. This research did not receive any specific grant from funding agencies in the public, commercial, or for profit sectors.

\section{REFERENCES}

Acosta y Asociados (2001). Preliminary atmospheric emissions inventory of mercury in Mexico. Final report. Project CEC-01. Prepared for the Commission for
Environmental Cooperation No. 3.2.1.04 [on line]. www.inecc.gob.mx/descargas/sqre/mxhg-airfinal_v2wmaps.pdf.

CEC (2011). Emisiones de mercurio. North american power plant air emissions. Commission for Environmental Cooperation [on line]. http://www2.cec.org/ site/PPE/es/hgemissions.

DEA (2017). Annual reports, strategic plans, and annual performance plans. Department of Environmental Affairs, Republic of South Africa [on line]. https://www. environment.gov.za/documents/reports.

DEE (2017). National Pollutant Inventory. Department of the Environment and Energy, Australian Government [on line]. http://www.npi.gov.au/resource/mercurycompounds

ECCC (2017). National Pollutant Release Inventory. Environment and Climate Change Canada [on line]. https://www.canada.ca/en/services/environment/ pollution-waste-management/national-pollutantrelease-inventory.html.

Fuentes G.G., Bravo A.H., Sosa E.R., Rosas A.S., Magaña R.V., Caetano D.E. and Vázquez C.G. (2017). Spatial and temporal variability of atmospheric mercury concentration emitted from a coal-fired power plant in Mexico. J. Air Waste Manag. Assoc. 67(9), 973985. DOI: $10.1080 / 10962247.2017 .1314871$

Galbreath K.C. and Zygarlicke C.J. (2000). Mercury transformations in coal combustion flue gas. Fuel Process. Technol. 65-66, 289-310. DOI: $10.1016 / \mathrm{S} 0378-3820(99) 00102-2$

Hassett D., Heebink L.V. and Pflughoeft-Hassett D.F. (2002). Potential of mercury vapor release from coal combustion by-products. Proceedings of Conference on Air Quality III: Mercury, Trace Elements, and Particulate Matter Conference. Energy \& Environmental Research Center, Grand Forks, North Dakota [on line]. www.netl.doe.gov/File\%20Library/Research/Coal/ ewr/solid\%20waste/EERC.pdf.

Hassett D.J., Heebink L.V. and Pflughoeft-Hassett D.F., (2004). Potential of mercury vapor release from coal combustion by-products. Fuel Process. Technol. 85 (6-7), 613-620. DOI: 10.1016/j.fuproc.2003.11.010

Heebink L.V. and Hassett D.J. (2005). Mercury release from FGD. Fuel 84 (11), 1372-1377.

DOI: 10.1016/j.fuel.2004.06.040

Larralde P.M. (2004). Informe final. Inventario Nacional de Liberaciones de Mercurio, México. Preparado para la Dirección de Investigación en Residuos y Sitios Contaminados del CENICA y para la Secretaría del Medio Ambiente y Recursos Naturales (SEMARNAT), Mexico [on line]. https://wedocs.unep.org/bitstream/ handle/20.500.11822/11367/MEXICO_Hg_Inventory_2004.pdf? sequence $=1 \&$ isAllowed $=\mathrm{y}$. 
MEFCC (2017). Hazardous substances management. Ministry of Environment, Forest and Climate Change, Government of India [on line]. http://www.moef.nic. in/division/reportguidelines

MEP (2016). Reports on the state of the environment in China. Ministry of Environmental Protection, People's Republic of China [on line]. http://english.sepa. gov.cn/Resources/Reports/soe/ReportSOE/201709/ P020170929573904364594.pdf.

Múgica V., Amador M.A., Torres M. and Figueroa J. (2003). Mercurio y metales tóxicos en cenizas provenientes de procesos de combustión e incineración. Rev. Int. Contam. Ambient. 19(2), 93-100.

NADP (2015). Mercury Deposition Network. National Atmospheric Deposition Program [on line]. http:// nadp.isws.illinois.edu/MDN/.

NRDC (2012). Health facts. Summary of recent mercury emission limits for power plants in United States and China. Natural Resources Defense Council [on line]. www.nrdc.org/sites/default/files/china-us-mercurylimits-FS.pdf.

Pacyna E.G., Pacyna J.M., Sundseth K., Munthe J., Kindbom K., Wilson S., Steenhuisen F. and Maxon P. (2010). Global emission of mercury to the atmosphere from anthropogenic sources in 2005 and projections to 2020. Atmos. Environ. 44 (20), 2487-2499.

DOI: 10.1016/j.atmosenv.2009.06.009

Pavlish J.H., Sondreal E.A., Mann M.D., Olson E.S., Galbreath K.C., Laudal D.L. and Benson S.A. (2003). Status review of mercury control options for coalfired power plants. Fuel Process. Technol. 82 (2-3), 89-165. DOI: 10.1016/S0378-3820(03)00059-6

Pirrone N., Munthe J., Barregard L., Ehrlich H.C., Petersen G., Fernandez R., Hansen J.C., Grandjean P., Horvat M., Steinnes E., Ahrens R., Pacyna J.M., Borowiak A., Boffeta P. and Wichmann-Fiebig M. (2001). Ambient air pollution by mercury $(\mathrm{Hg})$. Position paper. Office for Official Publications of the European Communities, Luxembourg.

Pirrone N., Cinnirella S., Feng X., Finkelman R.B., Friedli H.R., Leaner J., Mason R., Mukherjee A.B., Stracher G.B., Streets D.G. and Telmer K. (2010). Global mercury emissions to the atmosphere from anthropogenic and natural sources. Atmos. Chem. Phys. 10 (13), 5951-5964.

DOI: $10.5194 /$ acp-10-5951-2010

Schroeder W.H. and Munthe J. (1998). Atmospheric mercury - an overview. Atmos. Environ. 32 (5), 809-822. DOI: $10.1016 /$ S1352-2310(97)00293-8

SENER (2015). Programa de desarrollo del sistema eléctrico nacional 2016-2030. Secretaría de Energía, México, 158 pp. [en línea]. https://www.gob.mx/cms/uploads/ attachment/file/98308/PRODESEN-2016-2030_1.pdf.
Senior C.L., Sarofim A.F., Zeng T., Heldble J.J., MamaniPaco R. (2000). Gas-phase transformations of Mercury in coal-fired power plants. Fuel Process. Technol. 63 (2-3), 197-213.

DOI: 10.1016/S0378-3820(99)00097-1

Sosa E.R., Bravo A.H., Sánchez A.P., Fuentes G.G. and Rosas A.S. (2014). Estimations of mercury emissions in Mexico: Case coal-fired power plants. 107th Annual Conference \& Exhibition, Navigating Environmental Crossroads. June 24-27, Long Beach Center, California.

Sosa E.R., Bravo A.H., Sánchez A.P., Fuentes G.G., Rosas A.S. and Granados H.E. (2017). Estimación de emisiones de mercurio en las plantas carboeléctricas de México. Rev. Int. Contam. Ambie. 33(2), 325-336. DOI: 10.20937/RICA.2017.33.02.13

Streets D.G., Zhang Q. and Wu Y. (2009). Projections of global mercury emissions in 2050. Environ. Sci. Technol. 43 (8), 2983-2988. DOI: 10.1021/es802474j

UNEP (2013) Toolkit for identification and quantification of mercury sources, reference report and guideline for inventory level. United Nations Environment Program [on line]. www.inti.gob.ar/basilea/TallerMercurio/ Materialadicional/Toolkit/Nivel2/RevisedInventoryLevel\%202.pdf.

UNEP (2015). Minamata Convention on Mercury. United Nations Environment Program [on line]. www.mercuryconvention.org

USEPA (1997). Locating and estimating air emissions from sources of mercury and mercury compounds. Environmental Protection Agency [on line]. www.epa. gov/ttnchie1/le/mercury.pdf.

USEPA (2002). EPA-600/R-01-109. Control of mercury emissions from coal-fired power electric utility boilers. Interim report. United States Environmental Protection Agency, 485 pp.

USEPA (2005). Control of mercury emissions from coal fired electric utility boilers. United States Environmental Protection Agency [on line]. www.epa.gov/ airtoxics/utility/ord_whtpaper_hgcontroltech_oar2002-0056-6141.pdf.

USEPA (2011). EPA-454/R11-010. Electric Generating Utility Mercury Speciation Profiles for the Clean Air Mercury Rule. Environmental Protection Agency.

USEPA (2015a). Mercury. United States Environmental Protection Agency [on line]. www.epa.gov/mercury/.

USEPA (2015b). National emission standards for hazardous air pollutants compliance monitoring. United States Environmental Protection Agency [on line]. www.epa.gov/ttn/atw/188polls.html.

USEPA (2017). Air emissions inventories. United States Environmental Protection Agency [on line]. www.epa. gov/air-emissions-inventories. 
Vijay S., Molina L.T. and Molina M.J. (2004). Estimating air pollution emissions from fossil fuel use in the electricity sector in Mexico. North American Commission for Environmental Cooperation [on line]. www3.cec.org/ islandora/es/item/2166-estimating-air-pollution-emissions-from-fossil-fuel-use-in-electricity-sector-in-en.pdf.

Wang S.X., Zhang L., Li G.H., Wu Y., Hao J.M., Pirrone N., Sprovieri F. and Ancora M.P. (2010). Mercury emissions and speciation of coal fired-power plants in China. Atmos. Chem. Phys. 10 (3), 1183-1192.

DOI: $10.5194 /$ acp-10-1183-2010
Zhang L. and Wong M.H. (2007). Environmental mercury contamination in China: sources and impacts. Environ. Int. 33 (1), 108-121.

DOI: 10.1016/j.envint.2006.06.022

Zhang L., Zhou Y., Chen L., Xu X. and Chen C. (2008). Mercury emissions from six coal-fired power plants in China. Fuel Process. Technol. 89 (11), 1033-1040. DOI: 10.1016/j.fuproc.2008.04.002 


\section{APPENDIX 1. ESTIMATION OF MERCURY EMISSIONS TO THE ATMOSPHERE}

Two methods to determine mercury emissions to the atmosphere were developed by the USEPA (1998). The first one employs the mercury emission factor from the Compilation of air pollutant emission factors and the following equation:

$$
\text { Hg emission, } \frac{\mathrm{kg}}{\text { month }}=\left(\text { emission factor, } \frac{\mathrm{kg}, \mathrm{Hg}}{t, \text { coal }}\right)\left(\text { coal consumption, } \frac{t, \text { coal }}{\text { month }}\right)
$$

If a coal-fired power plant uses a control system that reduces mercury emissions, the emission factor to be used is then

$$
\text { Hg emission, } \frac{\mathrm{kg}}{\text { month }}=\left(3.8 \times 10^{-5} \frac{\mathrm{kg}, \mathrm{Hg}}{t, \text { coal }}\right)\left(\text { coal consumption, } \frac{t, \text { coal }}{\text { month }}\right)
$$

If a coal-fired power plant does not use a control system for mercury emissions, the emission factor to be used is $16 \mathrm{lb} / 10^{12} \mathrm{BTU}$.

The second method, developed by the USEPA in 1997, uses the mercury content in the combusted coal and the modified emission factor from which the follow equation is obtained for mercury emissions:

$$
H g \text { emission, } \frac{\mathrm{kg}}{\text { month }}=\left(\text { mercury consumption, } \frac{\mathrm{kg}, \mathrm{Hg}}{t, \text { coal }}\right)\left(\text { coal consumption, } \frac{t, \text { coal }}{\text { month }}\right)(M E F)
$$

The control systems used by coal-fired power plants in Mexico include electrostatic precipitators with a heating slide of value 1, as recommended in the developed USEPA- tables; however, mercury emissions are not retained in the control system because mercury is emitted as vapor.

To determine mercury emissions from the CETEPEC plant, we used the following equation, in accord with the USEPA methodology and a mercury content in coal of $0.333 \mathrm{mg} / \mathrm{kg}$, as determined by Múgica et al. (2003):

$$
\text { Hg emission, } \frac{\mathrm{kg}}{\mathrm{day}}=\left(0.333 \times 10^{-3} \frac{\mathrm{kg}, \mathrm{Hg}}{t, \text { coal }}\right)\left(\text { coal consumption, } \frac{t, \text { coal }}{\text { day }}\right)
$$

The fuel consumption was provided directly by the Federal Electricity Commission of Mexico, per day and per generating unit.

The results obtained for mercury emissions are presented in Figs. A1 to A12. 


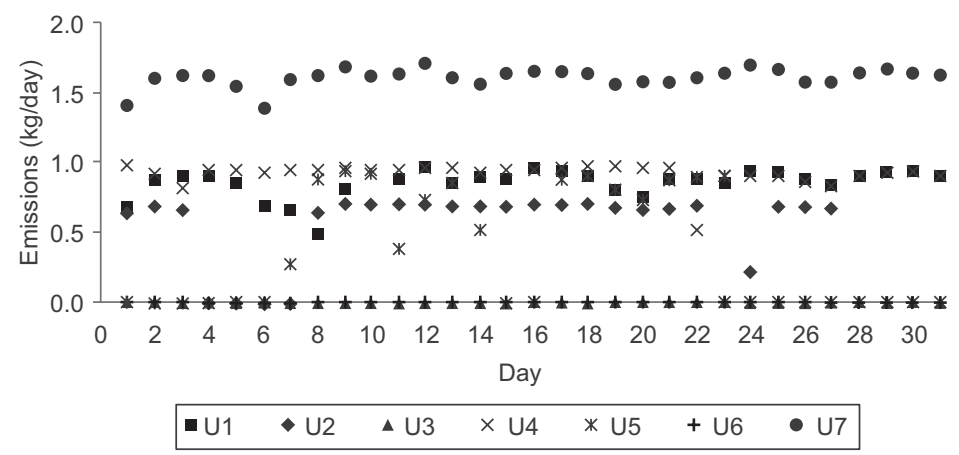

Fig. A1. Mercury emissions per day and per generating unit from CETEPEC, January 2013

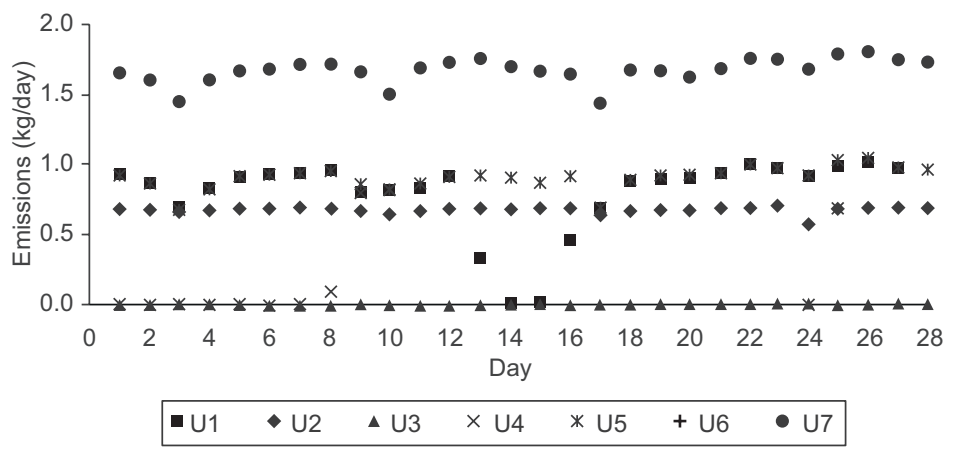

Fig. A2. Mercury emissions per day and per generating unit from CETEPEC, February 2013

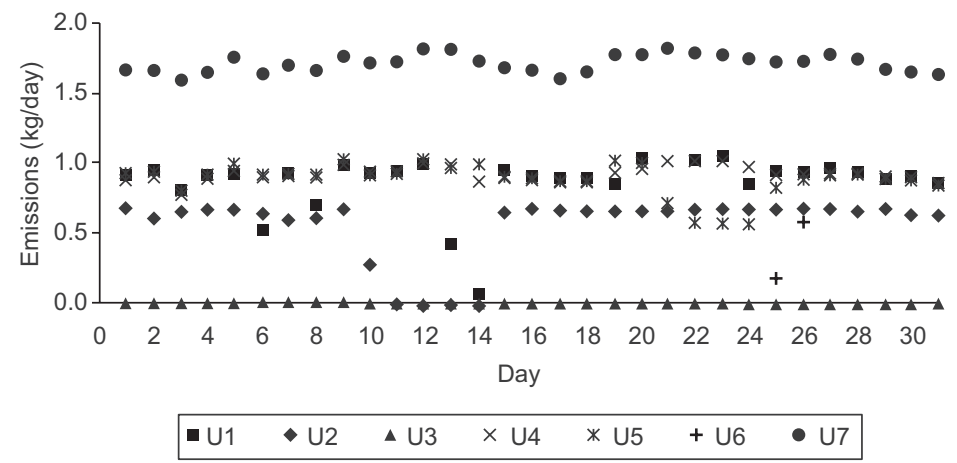

Fig. A3. Mercury emissions per day and per generating unit from CETEPEC, March 2013 


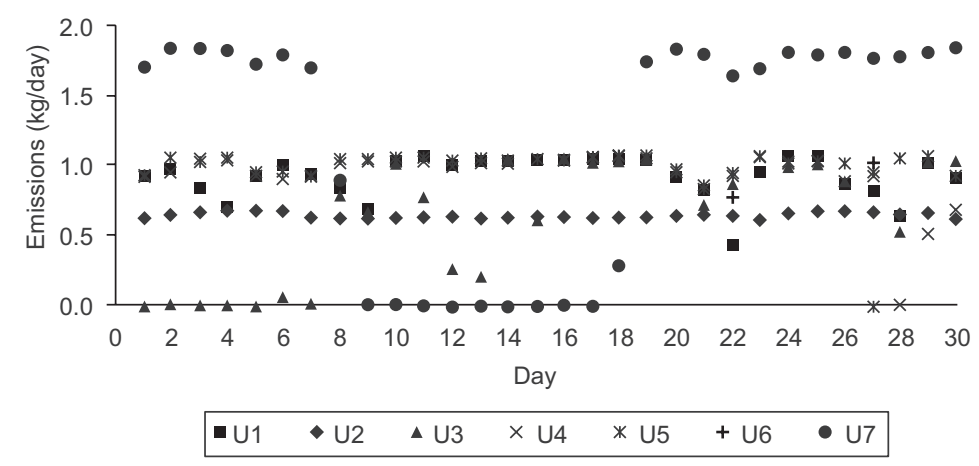

Fig. A4. Mercury emissions per day and per generating unit from CETEPEC, April 2013

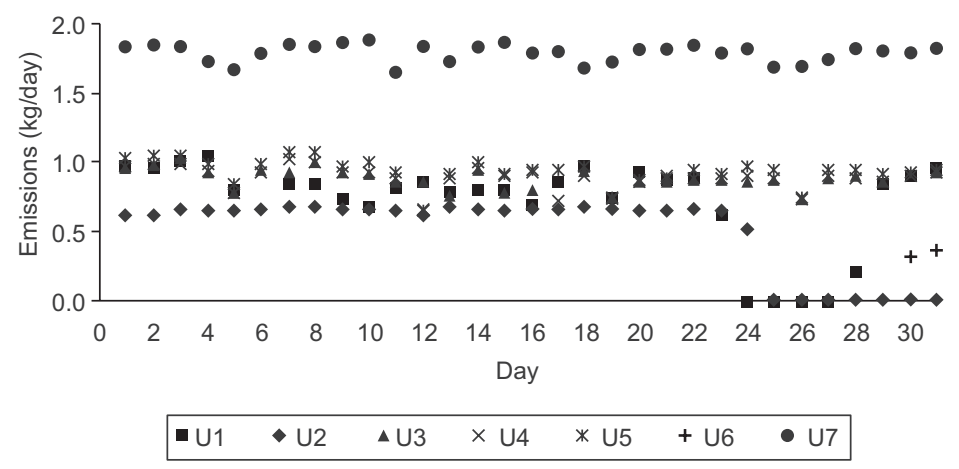

Fig. A5. Mercury emissions per day and per generating unit from CETEPEC, May 2013

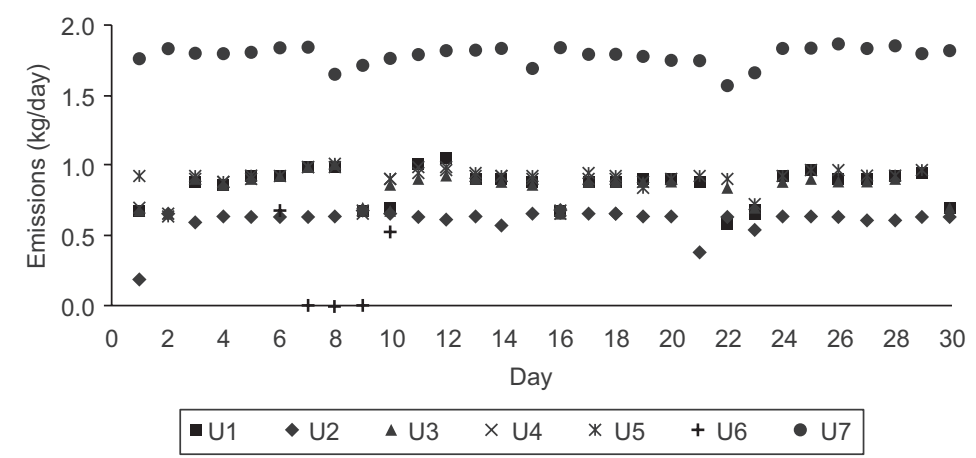

Fig. A6. Mercury emissions per day and per generating unit from CETEPEC, June 2013 


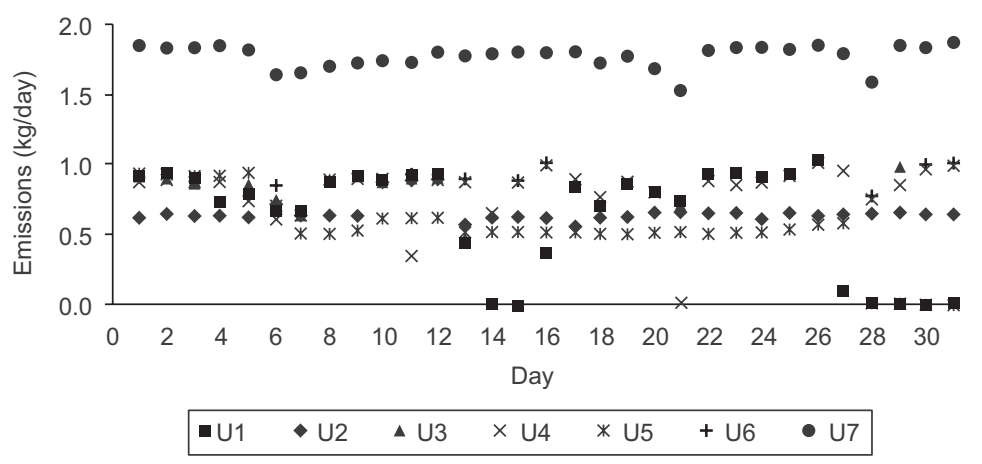

Fig. A7. Mercury emissions per day and per generating unit from CETEPEC, July 2013

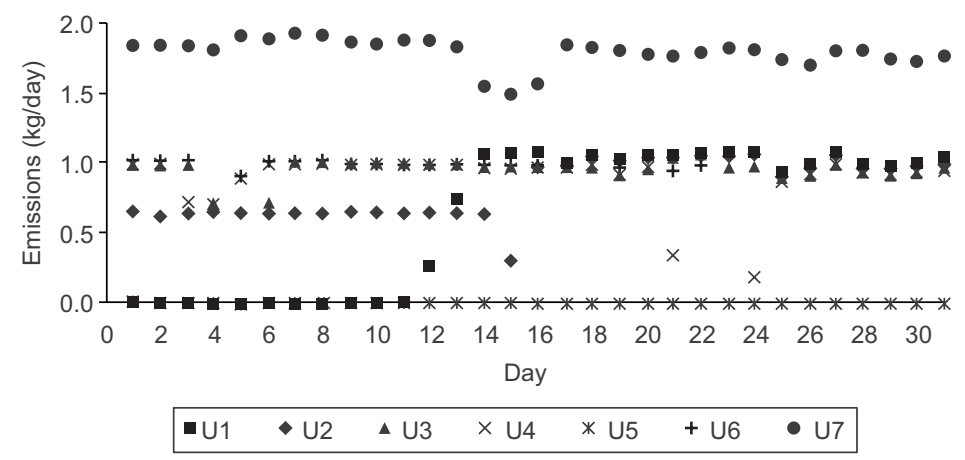

Fig. A8. Mercury emissions per day and per generating unit from CETEPEC, August 2013

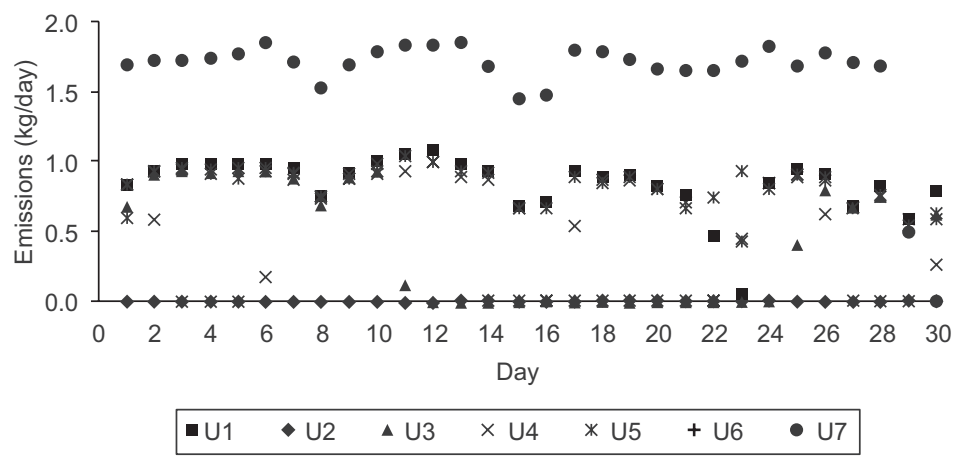

Fig. A9. Mercury emissions per day and per generating unit from CETEPEC, September 2013 


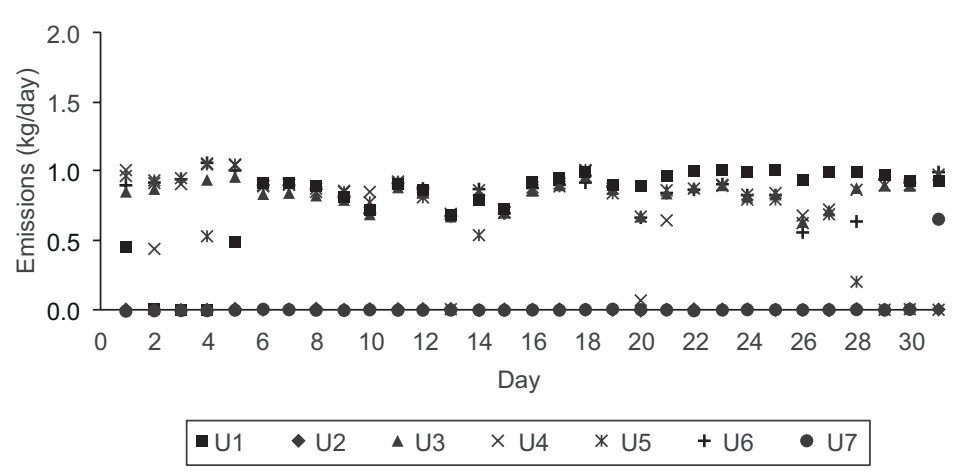

Fig. A10. Mercury emissions per day and per generating unit from CETEPEC, October 2013

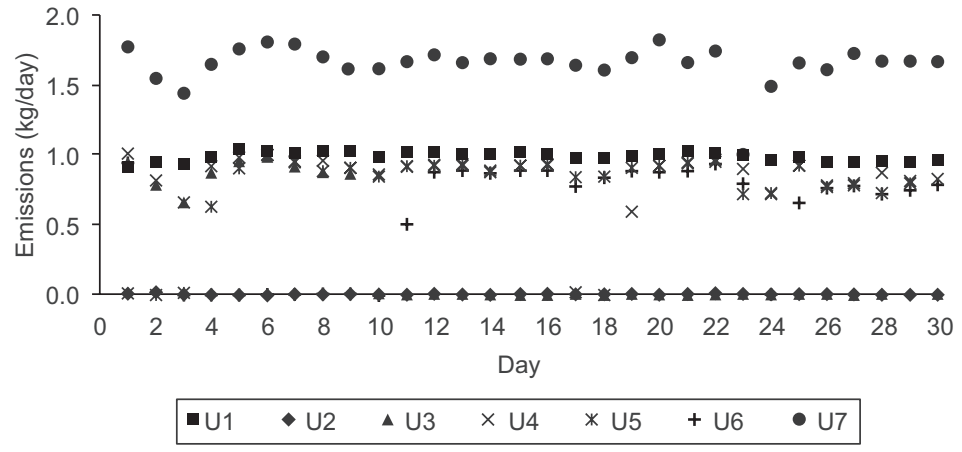

Fig. A11.Mercury emissions per day and per generating unit from CETEPEC, November 2013

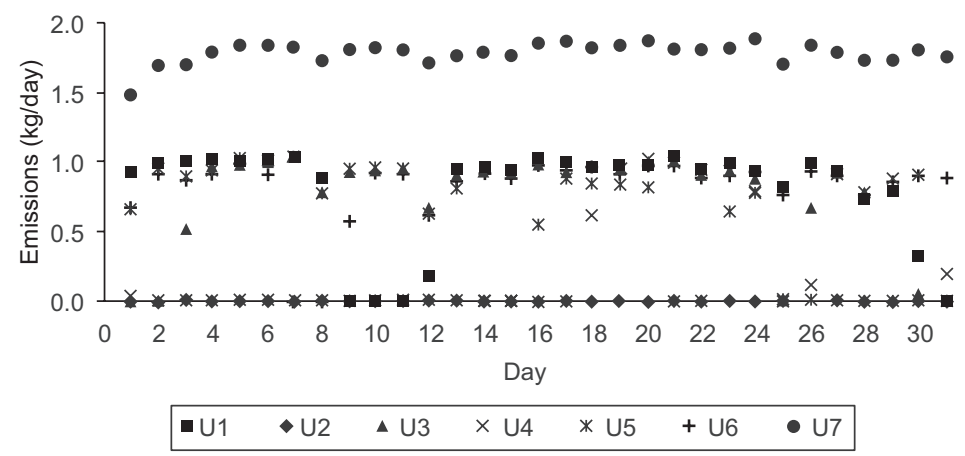

Fig. A12. Mercury emissions per day and per generating unit from CETEPEC, December 2013 